\title{
Path Analysis in Soybean Under Drought Stress and Co-inoculated With Azospirillum brasilense
}

\author{
Alessandra Maria de Lima Naoe ${ }^{1}$, Joênes Mucci Peluzio ${ }^{1}$, Lucas Koshy Naoe ${ }^{2}$, Leonardo José Motta Campos ${ }^{3}$ \\ \& Waldesse Piragé de Oliveira Júnior ${ }^{1}$ \\ ${ }^{1}$ Federal University of Tocantins, Palmas, Tocantins, Brazil \\ ${ }^{2}$ State University of Tocantins, Palmas, Tocantins, Brazil \\ ${ }^{3}$ Brazilian Agricultural Research Corporation, Palmas, Tocantins, Brazil \\ Correspondence: Alessandra Maria de Lima Naoe, Federal University of Tocantins, Palmas, Brazil. Tel: \\ 55-639-8123-8965.E-mail: alima@uft.edu.br
}

Received: November 8, 2018

Accepted: December 16, 2018

Online Published: February 15, 2019

doi:10.5539/jas.v11n3p311

URL: https://doi.org/10.5539/jas.v11n3p311

\begin{abstract}
The study was carried out with the objective of verifying the effect of the bacterium Azospirillum brasilense in the behavior of the morphological characteristics of cultivars soybean submitted to drought stress. Two experiments were carried in randomized blocks with a split-split plot design, with four replications. We evaluated the cultivars TMG 132 and ANTA 82. The treatments were subjected to two irrigation depths: total irrigation (100\% of crop evapotranspiration) and irrigation with drought stress (25\% of crop evapotranspiration) and co-inoculated with Azospirillum brasilense and inoculated whit only Bradyrhizobium japonicum. The coefficients of the correlation between the characteristics: leaf area, plant height, root length, number of nodules, shoot dry matter, root dry matter and nodule dry matter were analyzed, as well as the effects over the productivity through the path analisys. The drought stress did not alter the correlations between the studied characteristics; however the alteration happened due to the inoculation method. The path analysis showed that the root length was the only variable that had a direct effect on soybean grain yield, and this occurred only inoculation. In the co-inoculated treatments with Azospirillum brasilense, there were greater indirect effects in grain yield due the root dry matter and shoot dry matter.
\end{abstract}

Keywords: Glycine $\max (\mathrm{L}$.) Merrill, rhizobacterias, water deficit

\section{Introduction}

The interactions between plants and microorganisms are fundamental to the development and productivity of crops. The microorganisms performs important roles in plants increasing the bioavailability of soil-borne nutrients (Van der Heijden et al., 2008), growth hormone production (Verbon \& Liberman, 2016) and protection against pathogens (Mendes et al., 2013).

In soybean, the interaction with bacteria of the Bradyrhizobium genus is one of the determining factors to reach high yields due to the biological fixation of nitrogen, which is a sustainable source of the nutrient (Hungria, 2015). Besides, many studies have evaluated the interaction of plant growth-promoting rhizobacteria (PGPR) aiming to improve the performance of soybean crops (Hayat et al., 2010). Among these bacteria Azospirillum brasilense has shown promising results in crops (Benintende et al., 2010).

The use of Azospirillum brasilense, shows positive effects on the plants development (Kappes et al., 2013; Hungria et al., 2010), it influences on the architecture of the root (Cassán et al., 2009), increases the auxins levels (Zahedi \& Abbasi, 2015) and it may auxiliate on the elevation of abscisic acid-ABA (Cohen, 2015), in addittion to directly act on the increase over the drought stress tolerance of the plants (Aroca, 2012).

For soybean, a deficient water uptake causes variations in morphology root and aerial part, resulting in poorly developed plants with reduced leaf area, and low dry matter accumulation, which may reflect a decrease in productivity and quality of grains (Sepanlo et al., 2014). Therefore, it is necessary to find mechanisms that minimize the impact of the drought stress on the plants. The literature reports that the combined use of Azospirillum brasilense and Bradyrhizobium japonicum in soybean cultivation, through co-inoculation, has been 
recognized as a low cost biotechnological technique that improves plants morphology, with better response to adverse conditions (Hungria et al., 2015).

One approach to understand the effects of co-inoculation on plants and their relation to the environment is to study the correlations between their morphological characteristics in the presence/absence the bacterium in different water availability conditions. The knowledge of these correlations plays a fundamental role in measuring the degree of association between variables and assessing how much the change in one variable can affect the others (Cruz et al., 2012). It is noteworthy that, environmental variations can establish new correlations between the plants characters, this occurs due to a compensatory process to restore the physiological functions in the plant (Venable \& Brown, 1988). Thus, the environment becomes the cause of correlation when two characters are influenced by the same differences in environmental conditions (Gratani, 2014).

However, the correlations, by themselves, do not clearly explain the responses between the characters of plant. Therefore, it does not allow inferences about cause and effect, making it impossible to know which type of association governs the pair of characters. Thus, the study of path analysis, created by Wright (1921), allows us to unfold the correlation coefficients in direct and indirect effects on a basic variable, whose estimates are obtained by means of regression equations, in which the variables are previously standardized. Therefore, it is possible to investigate the effects of the basic variables over a dependent variable of economic interest (Trevisani et al., 2017).

Hence, the objective of this study was to investigate the correlation between morphological characteristics of two soybean cultivars under drought stress conditions and co-inoculated with Azospirillum brasilense and Bradyrhizobium japonicum, besides evaluating their direct and indirect effects over grain yield through path analysis.

\section{Material and Method}

\subsection{Location and Characterization of Experimental Area}

The experiments were conducted in the experimental area of the Federal University of Tocantins - UFT, Campus of Palmas-TO, Brazil, located at latitude 10 $12^{\prime} 46^{\prime \prime} \mathrm{S}$ and longitude 48 $21^{\prime} 37^{\prime \prime} \mathrm{W}$ and with an altitude of $260 \mathrm{~m}$, from June to November 2016. Two experiments were installed, the first sowing being performed on 01/06/2016 and the second one on 02/07/2016.

The climate in the region, according to Köeppen's climatic classification, is the humid tropical type with dry season (Aw) well defined in winter, which contributes to the high temperatures in the region. The annual average of the potential evapotranspiration is $1,500 \mathrm{~mm}$, presenting annual mean temperature and precipitation of $27.5^{\circ} \mathrm{C}$ and $1600 \mathrm{~mm}$ respectively (Inmet, 2014).

The soil of the experimental area is classified as dystrophic Red-Yellow Latosol (Embrapa, 2006), and had a sandy texture with low natural fertility (Table 1). The fertilization consisted in applying of $400 \mathrm{~kg} \mathrm{ha}^{-1}$ of simple superphosphate corresponding to $80 \mathrm{~kg}$ of $\mathrm{P}_{2} \mathrm{O}_{5} \mathrm{ha}^{-1}$ approximately

Table 1. Physical-chemical analysis of the soil before correction and fertilization

\begin{tabular}{|c|c|c|c|c|c|c|c|c|c|c|}
\hline \multicolumn{7}{|c|}{ Chemicals } & \multicolumn{4}{|c|}{ Physicals } \\
\hline $\mathrm{P}$ & $\mathrm{K}$ & $\mathrm{Ca}$ & $\mathrm{Mg}$ & $\mathrm{Al}$ & MO & $\mathrm{pH}\left(\mathrm{CaCl}_{2}\right)$ & Density & \multicolumn{3}{|c|}{ Granulometry (\%) } \\
\hline \multicolumn{2}{|c|}{---- $\mathrm{mg} \mathrm{dm}^{-3}$---- } & \multicolumn{2}{|c|}{$--\mathrm{cmol}_{\mathrm{c}} \mathrm{dm}^{-3}$-- } & \multicolumn{2}{|c|}{$--\mathrm{g} \mathrm{dm}^{-3}$--- } & & $-\mathrm{g} \mathrm{cm}^{-3}--$ & Clay & silt & sand \\
\hline 3.00 & 26.0 & 1.5 & 0.70 & 0.0 & 6.00 & 4.90 & 1.53 & 13.00 & 5.00 & 82.00 \\
\hline
\end{tabular}

Climatic data were collected daily from an automatic meteorological station, installed in the experimental area. The reference evapotranspiration (ETo) average in the period was $151.12 \mathrm{~mm}$, calculated by the Penman-Monteith-FAO method (Allen et al., 1998), and the cumulative precipitation was $127 \mathrm{~mm}$, obtained by reading weather station.

\subsection{Installation and Conduction of Experiments}

For evaluate the effects of bacterium on plants submitted to drought stress, the experiments was carried out in randomized block design, in a split-split plot design, with four replications, totaling 32 experimental units, for each sowing date. The treatments were divided into inoculant application methods: inoculation (IN)—(Bradirhyzobium japonicum) and co-inoculation (CO)—(Bradirhyzobium japonicum + Azospirillum 
brasilense) and irrigation depths: total irrigation (S1-100\% ETc) and irrigation with drought stress (S2-25\% ETc). The cultivars TMG 132 and ANTA 82, medium and early cycle, respectively, were used.

Each experimental plot consisted of four lines of $5 \mathrm{~m}$ long each, spaced $0.50 \mathrm{~m}$ between the rows and $1.0 \mathrm{~m}$ between treatments, with a density of 15 plants per linear meter.

It were used Azospirillum brasilense strains fluid AbV5 and AbV6 $\left(2.0 \times 10^{8} \mathrm{UFC} / \mathrm{mL}\right)$, and Bradirhyzobium japonicum Semia 5079 and Semia $5080\left(5.0 \times 10^{9} \mathrm{UFC} / \mathrm{mL}\right)$. The inoculation and co-inoculation were performed in the furrow, immediately after sowing. The doses used in the applications were: inoculation (600 $\mathrm{mL} 50 \mathrm{~kg}^{-1}$ seeds of Bradyrhizobium japonicum) e co-inoculation $\left(600 \mathrm{~mL}^{2} \mathrm{~kg}^{-1}\right.$ seeds of Bradyrhizobium japonicum $+400 \mathrm{~mL} \mathrm{ha}^{-1}$ of Azospirillum brasilense).

\subsection{Irrigation Management}

Two irrigation depths were adopted, S1 (total irrigation) and S2 (drought stress from R3). The irrigation system was through of drip with a polypropylene hose of $7 \mathrm{~cm}$ diameter with a flow of $1.71 \mathrm{~L} \mathrm{~h}^{-1}$ and spacing of $20 \mathrm{~cm}$ between the drippers. The system operated with Christiansen uniformity coefficient (CUC) of 96.75\%.

The irrigation management and the application of the depths were determined from the PenmanMonteith model FAO 56, which takes into account the evapotranspiration of the crop (ETc). The calculation of ETc was estimated by the product between the reference Evapotranspitation (ETo) and the crops coefficient (Kc), as described by. Climatic data were collected daily, always in the morning.

In S1, there was a replacement on the daily depth in $100 \%$ of the ETc during the whole cycle of the culture. For S2, the management occurred with full replacement of the depth untill the R3 stage, wich is the beginning of the pod formation. From R3, these treatments received daily leaf replacement of $25 \%$ of ETc and followed with drought stress until the end of the cycle. For TMG 132 cultivar drought stress occurred for 41 days in the first sowing and for 57 days in the second, in the ANTA 82 cultivar, the drought stress it was 38 days for the first sowing and 33 days for the second sowing.

Although the irrigation management had been through meteorological data, to ensure the efficiency of treatments with water déficit the soil moisture was monitored periodically by means of moisture check in field capacity and permanent wilting point. Through this information, it was possible to establish hydric conditions restrictively to the treatments in S2.

During the period of the two experiments there was a variation in the irrigation depths applied between the treatments from $203.06 \mathrm{~mm}$ to $533.5 \mathrm{~mm}$ for the first sowing season and $303 \mathrm{~mm}$ to $625 \mathrm{~mm}$ for the second sowing.

\subsection{Measurements}

The leaf area in $\mathrm{cm}^{2}$ (LA) was estimated by the indirect method (Benicasa, 1998), with adaptation of methodology proposed by Zeist et al. (2014). At stage R5.5, through a cylinder of a known area, leaf discs were removed of ten plants per plot, randomly selected. Based on the disks and leaves fresh mass in a precision scale of 0.001 gram, in relation to the disk area, LA was indirectly estimated.

Also in the R5.5 stage, five plants per plot were randomly collected andwere determined the root length (RL) and to count the number of nodules (NN), root dry matter (RDM), nodules dry matter (NDM) and shoot dry matter (SDM). At the R8 stage, the plant height (PH) and yield were determined. For the grain yield in kilograms per hectare (YIE), it was considered the $3 \mathrm{~m}^{2}$ plots useful area, eliminating the border effect.

\subsection{Statistical Analyzes}

Initially, Pearson correlation matrices were assembled to identify whether the associations between morphological characteristics (LA, PH, RL, NN, SDM, RDM and NDM) behaved in the same way, both in the sense and in the magnitude. For this, the effects of the irrigation depths (S1 and S2) and inoculation methods (IN and $\mathrm{CO}$ ) were isolated.

To the characteristics in which changes in the Pearson correlation were verified in function of the adopted management, it was proceeded with the path analysis.

Thus, the path coefficient was calculated, verifying the direct and indirect effects of these characteristics on the grain yield. It was considered a chain for the decomposition of the relations between the yield and the morphological characteristics. All analyzes were performed using the Genes computational statistical program (Cruz, 2013). 


\section{Results and Discussion}

\subsection{Pearson Correlations}

The phenotypic correlations between the morphological characteristics of two soybean cultivars, in two irrigation depths showed that in drought stress was not able to promote changes between correlations in this condition (Table 2).

Table 2. Phenotypic correlations for morphological characteristics of soybean under two irrigation depths, S1 $(100 \% \mathrm{ETc})$ and S2 (25\% ETc) and under two inoculant application methods: inoculation (IN) with with Bradyrhizobium japonicum and co-inoculation (CO) with Bradyrhizobium japonicum + Azospirillum brasilense

\begin{tabular}{llllllll}
\hline & LA & PH & RL & NN & SDM & RDM & NDM \\
\hline LA & & $0.725^{*}$ & $-0.08^{\mathrm{ns}}$ & $0.337^{\mathrm{ns}}$ & $0.428^{\mathrm{ns}}$ & $0.594^{\mathrm{ns}}$ & $0.060^{\mathrm{ns}}$ \\
PH & $0.709^{*}$ & & $-0.254^{\mathrm{ns}}$ & $0.320^{\mathrm{ns}}$ & $0.884^{* *}$ & $0.913^{* *}$ & $0.192^{\mathrm{ns}}$ \\
RL & $0.056^{\mathrm{ns}}$ & $-0.192^{\mathrm{ns}}$ & & $0.284^{\mathrm{ns}}$ & $-0.402^{\mathrm{ns}}$ & $-0.366^{\mathrm{ns}}$ & $-0.053^{\mathrm{ns}}$ \\
$\mathrm{NN}$ & $0.208^{\mathrm{ns}}$ & $-0.187^{\mathrm{ns}}$ & $0.520^{\mathrm{ns}}$ & & $0.298^{\mathrm{ns}}$ & $0.481^{\mathrm{ns}}$ & $0.608^{*}$ \\
SDM & $0.371^{\mathrm{ns}}$ & $0.812^{*}$ & $-0.459^{\mathrm{ns}}$ & $-0.622^{\mathrm{ns}}$ & & $0.962^{* *}$ & $0.335^{\mathrm{ns}}$ \\
RDM & $0.699^{\mathrm{ns}}$ & $0.954^{* *}$ & $-0.328^{\mathrm{ns}}$ & $-0.312^{\mathrm{ns}}$ & $0.908^{* *}$ & & $0.439^{\mathrm{ns}}$ \\
NDM & $0.012^{\mathrm{ns}}$ & $-0.142^{\mathrm{ns}}$ & $0.274^{\mathrm{ns}}$ & $0.668^{*}$ & $-0.381^{\mathrm{ns}}$ & $-0.249^{\mathrm{ns}}$ &
\end{tabular}

Note. Values above the main diagonal indicate S1 $(100 \% \mathrm{ETc})$, values below the main diagonal indicate S2 (25\% $\mathrm{ETc}) . * *, *$ significant correlation at $1 \%$ and $5 \%$ probability by the $\mathrm{t}$ test; respectively; ns: not significant. LA: leaf area; PH: plant height; RL: root length; NN: number of nodules; SDM: shoot dry matter; RMD: root dry matter; NDM: nodule dry matter.

The leaf area (LA) presented significant correlation of high magnitude and positive direction with $\mathrm{PH}$ in S1 (0.725) and S2 (0.709) (Table 2). Similar results were found by Silva et al. (2009), whose observation did a correlation coefficient of 0,79 among these characteristics in soybean plants well-watered. This correlation may indicate that an increase in leaf area gives a higher plant growth, probably due to the greater light and $\mathrm{CO}_{2}$ uptake and, therefore, a higher photosynthetic rate, which favors the processes of synthesis and nutrients translocation in plants. However, a greater leaf area also implies a greater water loss, although the plants can limit the drought effects through phenotypic plasticity, which is considered one of the major means by which plants can cope with the variability of the environmental factor (Gratani, 2014). This capacity of adaptation may include changes on the leaf and root morphology. In addition, the plant can improve water uptake in the presence of Azospirillum brasilense (Bashan \& De-Bashan, 2010), mainly in dry weather periods.

In addition, in $\mathrm{S} 1$ and $\mathrm{S} 2$, the correlation between $\mathrm{PH}$ and $\mathrm{SDM}(0.884,0.812)$ and $\mathrm{RDM}(0.913,0.954)$ were also high and positive in the two irrigation depths. An analogous situation was verified between SDM and RDM $(0.962,0.908)$. These results indicate that the source/sink relationship was maintained in the two hydric conditions, contributing with positive responses between plant growth and root development and vice versa.

Another positive correlation was observed in relation to the number of nodules and nodule dry matter $(0.608$, 0.668), which is an expected situation, because a condition that allows the increasing number of nodules in the roots tends to favor the dry mass of it, since these characteristics are dependent, this situation was also maintained in the two irrigation depths evaluated.

Therefore, the correlations observed in S1 and S2 were of magnitude and similar signs, and that, in none of them, there was a change when the hydric availability changed (Table 2). These results indicate that there was no environmental interference of the irrigation depths, or that drought stress, alone, was not able to promote alterations on the correlations between the studied characteristics. That may be related to the mechanisms of tolerance to the water stress of cultivars, which may be more efficient depending on each plant. That mechanism is related to the root development, on wich the plant may invests a greater amount of photoassimilates for the root growth, increaseasing the water absorption in dry conditions, and therefore, alteringthe root/shoot ratio.

On the other hand, when inoculation methods were isolated, the results showed a change in leaf area correlations (LA) and root length (RL) with the other characteristics, when analyzed in IN and CO (Tabela 3). 
Table 3. Phenotypic correlations for morphological characteristics of soybeans under two inoculant application methods: inoculation (IN) with with Bradyrhizobium japonicum and co-inoculation (CO) with Bradyrhizobium japonicum + Azospirillum brasilense and under two irrigation depths, S1 (100\% ETc) and S2 (25\% ETc)

\begin{tabular}{|c|c|c|c|c|c|c|c|}
\hline & LA & $\mathrm{PH}$ & RL & $\mathrm{NN}$ & SDM & $\mathrm{RDM}$ & NDM \\
\hline LA & & $0.863^{* *}$ & $-0.406^{\mathrm{ns}}$ & $0.276^{\mathrm{ns}}$ & $0.416^{\mathrm{ns}}$ & $0.628^{\text {ns }}$ & $0.279^{\mathrm{ns}}$ \\
\hline $\mathrm{PH}$ & $0.565^{\text {ns }}$ & & $-0.579^{\mathrm{ns}}$ & $0.427^{\mathrm{ns}}$ & $0.765^{*}$ & $0.898^{* *}$ & $0.337^{\mathrm{ns}}$ \\
\hline RL & $0.283^{\mathrm{ns}}$ & $-0.109^{\mathrm{ns}}$ & & $0.003^{\mathrm{ns}}$ & $-0.845^{* *}$ & $-0.751^{*}$ & $-0.382^{\mathrm{ns}}$ \\
\hline $\mathrm{NN}$ & $0.287^{\mathrm{ns}}$ & $-0.200^{\mathrm{ns}}$ & $0.608^{\mathrm{ns}}$ & & $0.216^{\mathrm{ns}}$ & $0.503^{\mathrm{ns}}$ & $0.688^{*}$ \\
\hline SDM & $0.373^{\text {ns }}$ & $0.938^{* *}$ & $-0.278^{\mathrm{ns}}$ & $-0.493^{\mathrm{ns}}$ & & $0.921 * *$ & $0.383^{\mathrm{ns}}$ \\
\hline RDM & $0.639^{\mathrm{ns}}$ & $0.987 * *$ & $-0.066^{\mathrm{ns}}$ & $-0.211^{\mathrm{ns}}$ & $0.934 * *$ & & $0.595^{\mathrm{ns}}$ \\
\hline NDM & $-0.214^{\mathrm{ns}}$ & $-0.257^{\mathrm{ns}}$ & $0.307^{\mathrm{ns}}$ & $0.648^{*}$ & $-0.419^{\mathrm{ns}}$ & $-0.350^{\mathrm{ns}}$ & \\
\hline
\end{tabular}

Note. Values above the main diagonal indicate $\mathrm{CO}$ (coinoculation), values below the main diagonal indicate IN (inoculation). ${ }^{* *},{ }^{*}$ significant correlation at $1 \%$ and $5 \%$ probability by the $t$ test; respectively; ns: not significant. LA: leaf area; PH: plant height; RL: root length; NN: number of nodules; SDM: shoot dry matter; RDM: root dry matter; NDM: nodule dry matter.

For the leaf area (LA) and root length (RL), when the isolated effect inoculation with Bradyrhizobium japonicum was considered, no significant correlations were verified with any of the characteristics studied. Possibly indicating that the inoculation with Bradirhyzobium japonicum did not influence the effects of one characteristic on the other.

However, in the coinoculated treatments, new correlations were established. For LA, there was a significant and positive correlation with PH (0.883). This may indicate that the Azospirillum has an effect on the physiological relationships of photoassimilates distribution by the plant (Jafarian et al., 2017).

Another change observed in co-inoculation is related to the root length (RL), which presented a high and negative correlation with SDM (-0.845) and RDM (-0.751). The high inverse correlation with RDM indicates that an increase in the length of the main root tends to reduce the dry matter of the same or vice versa. According to $\mathrm{Wu}$ et al. (2016), the root dry matter can not provide single specific information on the root arrangement in the soil, it is important to note that the root diameter may present to the roots dry matters similar values but different in length. In this case, the inverse correlation may indicate, for example, an increase of secondary lateral roots with the reduction in the diameter of the main root.

The phytohormones produced by Azospirillum brasilense play an important role over the roots formation and architecture. This implies in the process of elongation, as well as the formation of lateral roots and root hairs (Gulii et al., 2015).

Cassán et al. (2009) verified that the lateral root growth and inhibition of the root lengthening occurred in maize plants inoculated with Azospirillum brasilense. A similar result was reported by Cohen et al. (2015), in which Arabidopsis thaliana plants inoculated with Azospirillum, had the structure of the root modified, with greater growth of lateral roots in detriment of the main root. It was also observed that the inoculation of Azospirillum increased the the leaf water content, mitigating the drought stress in plants.

It is important to reinforce that the root length did not present a correlation between the other characteristics when studied in S1, S2 and IN. This difference was only observed in the co-inoculated treatments, reinforcing the effects of Azospirillum brasilense over the growth and modification in root architecture.

In addition, RL and SDM also had high negative correlation when they were co-inoculated, which may suggest a divergent cause and effect relationship, indicating that a greater accumulation of dry matter would have negative effects on the root length, or vice versa. A possible explanation would be regarding the metabolic cost of an increasing the root length, making imbalance of the source/sink ratio and impairing the development of the aerial part of the plant.

Related to SDM, RDM and PH, there was a high and positive correlation in IN and CO, as well as in S1 and S2. Therefore, it can be inferred that the variations on those characteristics are mutually explained, in other words, they are dependent, and their correlations were not altered as a function of the treatments.

Thus, the co-inoculation with Azospirillum brasilense altered the behavior only for the leaf area and root length characteristics, suggesting a change in the source/sink relations of the plant. 


\subsection{Path Analysis}

For the path analysis (Table 4), it was considered the characteristics that had their altered correlations in function of the treatment, that was noticed for the leaf area (LA) and for the root lenght (RL) on the correlation matrix (Table 3). The path analysis of the dry factor was not performed because it did not present changes on the correlations between the characteristics studied.

The coefficients of determination $\left(\mathrm{R}^{2}\right)$ in the path analysis model were higher than 0.999 and the residual effects were lower than 0.002 or null. According to Alcântara Neto et al. (2011), the high value of determination coefficients of the path and the low effect of the residual variable, evidences a strong cause and effect relationship between the studied attributes and their correlations with the grain production, thus representing a positive point in the path analysis.

Thereby, the study of the path analysis made it possible to decompose the factors that resulted in the observed correlations, and how the inoculation and co-inoculation have influenced the direct and indirect effects of those correlations over the grain yield.

The analysis recorded some coefficient values that were higher than the unity (Table 4). According to Grace and Bollen (2005), this is possible because of the path coefficients are estimated based on standardized data, so they were obtained in the same way as the regression coefficients.

Table 4. Estimates of inoculation (IN) and co-inoculation (CO) effects of morphological characteristics leaf area (LA) and root length (RL) on grain yield in soybean

\begin{tabular}{|c|c|c|c|}
\hline \multirow{2}{*}{ Characteristic } & \multirow{2}{*}{ Effects } & \multicolumn{2}{|c|}{ Path coefficient } \\
\hline & & $\mathrm{IN}$ & $\mathrm{CO}$ \\
\hline \multirow[t]{8}{*}{ Leaf área (LA) } & Direct effect on YIE & 1.39 & 2.92 \\
\hline & Indirect effect via $\mathrm{PH}$ & 2.61 & 0.86 \\
\hline & Indirect effect via RL & 0.23 & -0.24 \\
\hline & Indirect effect via $\mathrm{NN}$ & -0.04 & 0.35 \\
\hline & Indirect effect via SDM & 0.29 & 3.17 \\
\hline & Indirect effect via RDM & -3.80 & -6.67 \\
\hline & Indirect effect via NDM & 0.12 & 0.48 \\
\hline & Total & 0.81 & 0.87 \\
\hline \multirow[t]{8}{*}{ Root lenght (RL) } & Direct effect on YIE & 0.83 & 0.60 \\
\hline & Indirect effect via LA & 0.39 & -1.18 \\
\hline & Indirect effect via $\mathrm{PH}$ & -0.50 & -0.57 \\
\hline & Indirect effect via NN & -0.10 & 0.04 \\
\hline & Indirect effect via SDM & -0.22 & -6.43 \\
\hline & Indirect effect via RDM & 0.39 & 7.98 \\
\hline & Indirect effect via NDM & -0.18 & -0.66 \\
\hline & Total & 0.61 & -0.27 \\
\hline $\mathrm{R} 2$ & & 0.9999 & 1.0000 \\
\hline Residual effect & & 0.001 & null \\
\hline
\end{tabular}

The biggest direct effect on the yield was observed for leaf area (LA), on both treatments. Positive direct effects of high magnitude were detected in IN (1.39) and CO (2.92). Beside this, both presented high correlations with the response variable (0.81 and 0.87) diverging from the results found by Zuffo et al. (2009), where the height of the plant was the variable with the greatest direct effect on grain yield, in soybean inoculated with Azospirillum brasilense.

Although these correlations between yield and leaf area were positive and high in both treatments, the path analysis showed that they have different natures. In the inoculation (IN), the indirect effect via PH (2.61) in the relation between leaf area and yield of grains exceeded the direct effect (1.39). In this case, larger plants would have a higher productivity. In addition, other positive indirect effects of lower magnitude were observed via RL (0.23), SDM (0.29) and NDM (0.12). There was also an indirect negative effect of great importance via RDM 
(-3.80), which can be explained by the source/sink relation and competition for photoassimilates (Silva et al., 2016).

These results suggest that the inoculation with Bradirhyzobium japonicum may have promoted effects on productivity, with the increase of the leaf area, however on the $\mathrm{PH}$ route, which was not observed in the co-inoculation. In co-inoculation (CO), the direct effect of LA (2.92) on productivity was overcome by the indirect effect via SDM (3.17). According to Bashan (2005), bacterias of the genus Azospirillum promotes the plant growth through several mechanisms, such as nitrogen fixation and phytohormone production, stimulating root branching and increasing shoot and root biomass, which could explain the magnitude of the indirect effect via shoot dry matter. Other indirect positive effects were also observed in PH (0.86), NN (0.35) and NDM (0.48).

The indirect pathway RL (-0.24) in coinoculation had a similar magnitude to IN (0.23), but with a negative signal, and the indirect effect via RDM (-6.67), despite of the same direction it has presented a higher magnitude in $\mathrm{CO}$, when compared to IN (-3.80). These results suggest that the presence of Azospirillum brasilense promoted changes on the assimilates distribution, from the shoot to the root. That can occur due to the increase of the root system, stimulated by the Indole-3-acetic acid (IAA) and produced by the bacterium (Molina et al., 2018), resulting in greater cellular activity in the root, directing the assimilate partition to the site.

In the relationship between the root length (RL) and yield of grains (YIE), it was verified that in the inoculation (IN) the direct effect of RL (0.83) was higher than the indirect effects, although no significant correlation was observed with the yield of grains (0.61) (Table 4). In addition, the path showed a strong positive indirect effect through LA (0.39) and RDM (0.39) and negative via PH (-0.50), NN (-0.10) and NDM (-0.18). Thus, the low correlation observed between RL and YIE probably occurred due to PH, NN and NDM indirect pathways. Thus, it can be inferred that the bacterium Bradirhyzobium japonicum influences the root growth, due to the increase nitrogen by the biological fixation, which does not necessarily promote an increase in grain yield.

Regarding the co-inoculation (CO), the direct effect of RL (0.60) on productivity was overcomed by the indirect effect of RDM (7.98). The high value of the observed path coefficient for root dry matter suggests that Azospirillum brasilense has effects on root growth, but with a greater stimulus in the growth of lateral roots and root hairs. Burdmann et al. (2000) verified that the co-inoculation of Azospirillum brasilense in legumes stimulates the development of lateral roots, density and branching of root hair, due to the induction of nod genes production. It is worthy to mention that the correlation between RL and RDM was high and negative in co-inoculation (Table 3), which reinforces the observed effects on RL, via RDM for yield.

Another indirect effect of importance was verified in SDM (-6.43), the direction of this effect may explain in part the fact that no significant correlation between the root length and the grain yield in the co-inoculation was observed. Recalling that RL also presented high and negative correlation with SDM (Table 3).

In every case, it is important to note that the presence of the bacterium Azospirillum brasilense has modified the pathways in cause and effect relationships with productivity, and that the greatest effects observed were related to the morphological changes in the root structure.

\section{Conclusions}

The drought stress, did not alone promote changes on the correlations between the studied characteristics. The path analysis showed that the root length was the only variable that had a direct effect on soybean grain yield, and that occurred only at the inoculation. In the co-inoculated treatments with Azospirillum brasilense, there a greater indirect effects on grain yield for the root dry matter and shoot dry matter.

\section{References}

Alcântara Neto, F., Gravina, G. A., Monteiro, M. M. S., Morais, F. B., Petter, F. A., \& Albuquerque, J. A. A. (2011). Análise de trilha do rendimento de grãos de soja na microrregião do Alto Médio Gurguéia. Comunicata Scientiae, 2(2), 107-112.

Allen, R. G., Pereira, L. S., Raes, D., \& Smith, M. (1998). Crop evapotranpiration: Guidelines for computing crop water requirements. FAO Irrigation and Drainage, Paper 56 (p. 300). Rome.

Aroca, R., Porcel, R., \& Ruiz-Lozano, J. M. (2012). Regulation of root water uptake under abiotic stress conditions. Journal of Experimental Botany, 63(1), 43-57. https://doi.org/10.1093/jxb/err266

Bashan, Y., \& de-Bashan, L. E. (2010). How the plant growthpromoting bacterium Azospirillum promotes plant growth-A critical assessment. Advances in Agronomy, 108, 77-136. https://doi.org/10.1016/S0065-2113(10) 08002-8 
Bashan, Y., \& de-Bashan, L. E. (2005). Plant Growth-Promoting (1st ed.). In D. Hillel (Ed.), Encyclopedia of Soils in the Environment (pp. 103-115). Oxford: Elsevier. https://doi.org/10.1016/B0-12-348530-4/00513-0

Benintende, S., Uhrich, W., Herrera, M., Gangge, F., Sterren, M., \& Benintende M. (2010). Comparación entre coinoculación com Bradyrhizobium japonicum y Azospirillum brasilense e inoculación simple con Bradyrhizobium japonicum en la nodulación, crecimiento y acumulación de $\mathrm{N}$ en el cultivo de soja. Agriscientia, 23(2), 71-77.

Burdmann, S., Hamaoui, B., \& Okon, Y. (2000). Improvement of legume crop yields by coinoculation with Azospirillum and Rhizobium. The Otto Warburg Center for Agricultural Biotechnology (pp. 145-152). Israel: The Hebrew University of Jerusalem.

Cassán, F., Perrig, D. S., Sgroy, V., \& Luna, M. V. (2009). Azospirillum brasilense Az39 and Bradyrhizobium japonicum E109, inoculated singly or in combination, promote seed germination and early seedling growth in corn (Zea mays L.) and soybean (Glycine max L.). European Journal of Soil Biology, 45(1), 28-35. https://doi.org/10.1016/j.ejsobi.2008.08.005

Cohen, A. C., Bottini, R., Pontim, M., Berli, F. J., Moreno, D., Boccanlandro, H., ... Piccoli, P. N. (2015). Azospirillum brasilense ameliorates the response of Arabidopsis thaliana to drought mainly via enhancement of ABA levels. Physiologia Plantarum Journal, 153(1), 79-90. https://doi.org/10.1111/ ppl.12221

Cruz, C. D., Regazzi A. J., \& Carneiro, P. C. S. (2012). Modelos biométricos aplicados ao melhoramento genético (p. 512). UFV, Viçosa, Brasil.

Cruz, C. D. (2013). GENES: A software package for analysis in experimental statistics and quantitative genetics. Acta Scientiarum Agronomy, 35(3), 271-276. https://doi.org/10.4025/actasciagron.v35i3.21251

Embrapa (Empresa Brasileira de Pesquisa Agropecuária). (2006). Centro Nacional de Pesquisa do Solo. Sistema brasileiro de classificação de solos (2nd.ed.). Rio de Janeiro, Embrapa Solos.

Grace, J. B., \& Bollen, K. A. (2005). Interpreting the results from multiple regression and structural equation models. Ecological Society of America, 86(4), 283-295. https://doi.org/10.1890/0012-9623(2005)86 [283:ITRFMR]2.0.CO;2

Gratani, L. (2014). Plant phenotypic plasticity in response to environmental factors. Advances in Botany, 2014, 1-17. https://doi.org/10.1155/2014/208747

Gulii, O. I., Sokolova, M. K., Sokolov, O. I., \& Ignatov, O.V. (2015). Changes in the Morohology of the Root Sustem of Wheat Inoculated With Azospirillum brasilense Sp7 and Bacteriophage Fab-Sp7. Agricultural Biology, 50(3), 315-322.

Hungria, M., Campo, R. J., Souza, E. M., \& Pedrosa, F. O. (2010). Inoculation with selected strains of Azospirillum brasilense and A. lipoferum improves yields of maize and wheat in Brazil. Plant and Soil, 331(1-2), 413-425. https://doi.org/10.1007/s11104-009-0262-0

Hayat, R., Ali, S., Amara, U., Khalid, R., \& Ahmed, I. (2010). Soil beneficial bactéria and their role in plant growth promotion: A review. Ann. Microbiol., 60, 579-598. https://doi.org/10.1007/s13213-010-0117-1

Hungria, M., Nogueira, M. A., \& Araújo, R. S. (2015). Soybean seed co-inoculation with Bradyrhizobium spp. and Azospirillum brasilense: A new biotechnological tool to improve yield and sustainability. American Journal of Plant Science, 6(10), 811-817. https://doi.org/10.4236/ajps.2015.66087

National Institute of Meteorology (Inmet). (2014). Agroclimatological Bulletin (p. 20). Brazil.

Jafarian, T., Zarea, M. J., \& Siosemardeh, A. (2017). Histological Responses of Two Wheat Species to Azospirillum Inoculation under Dryland Farming. Journal of Plant Physiology and Breeding, 7(2), 67-79.

Kappes, C., Arf, O., Arf, M. V., Ferreira, J. P., Dal Bem, E. A., Portugal, J. R., \& Vilela, R. G. (2013). Inoculação de sementes com bactéria diazotrófica e aplicação de nitrogênio em cobertura e foliar em milho. Semina: Ciências Agrárias, 34(2), 527-538. https://doi.org/10.5433/1679-0359.2013v34n2p527

Martínez-Morales, L. J., Soto-Urzúa, S., Baca, B. E., \& Sánches-Ahédo, J. A. (2003). Indole-3-butyric acid (IBA) production in culture medium by wild strain Azospirillum brasilense. FEMS Microbiology Letters, 228(2), 167-173. https://doi.org/10.1016/S0378-1097(03)00694-3 
Mendes R., Garbeva P., \& Raaijmakers J. M. (2013). The rhizosphere microbiome: Significance of plant beneficial, plant pathogenic, and human pathogenic microorganisms. FEMS Microbiol. Rev, 37, 634-663. https://doi.org/10.1111/1574-6976.12028

Molina, R., Rivera, D., Mora, V., López, G., Rosas, S., Spaepen, S., ... Cássan, F. (2018). Regulation of IAA Biosynthesis in Azospirillum brasilense Under Environmental Stress Conditions. Current Microbiology, 75(10), 1408-1418. https://doi.org/10.1007/s00284-018-1537-6

Sepanlo, N., Talebi, R., Rokhzadi, A., \& Hayedeh, M. (2014). Morphological and physiological behavior in soybean (Glycine max) genotypes to drought stress implemented at pre- and post-anthesis stages. Acta Biologica Szegediensis, 58(2), 109-113.

Silva, C. A., Schmildt, E. R., Schmildt, O., Alexandre, R. S., Cattaneo, L. F., Ferreira, J. P., \& Nascimento, A. L. (2016). Correlações fenotípicas e análise de trilha em caracteres morfoagronômicos de mamoeiro. Revista Agro@mbiente, 10(3),217-227. https://doi.org/10.18227/1982-8470ragro.v10i3.3021

Silva, A. F. (2009). Interferência de plantas daninhas em diferentes densidades no crescimento da soja. Planta Daninha, 27(1), 75-84. https://doi.org/10.1590/S0100-83582009000100011

Trevisani, N., Melo, R. C., Colli, M. P., Coimbra, J. L. M., \& Guidolin, A. F. (2017). Associations Between Traits in Fisális: A Toll for Indirect selection of Superior Plants. Rev. Bras. Frut., 39(4), 1-7. https://doi.org/10.1590/0100-29452017106

Venable, L., \& Brown, J. (1988). The Selective Interactions of Dispersal, Dormancy, and Seed Size as Adaptations for Reducing Risk in Variable Environments. The American Naturalist, 131(3), 360-384. https://doi.org/10.1086/284795

Van der Heijden, M. G. A., Bardgett, R. D., \& Van Straalen, N. M. (2008). The unseen majority: Soil microbes as drivers of plant diversity and productivity in terrestrial ecosystems. Ecology. Letters, 11(6), 296-310. https://doi.org/10.1111/j.1461-0248.2007.01139.x

Verbon, E. H., \& Liberman, L. M. (2016). Beneficial microbes affect endogenous mechanisms controlling root development. Trends Plant Sci., 21, 218-229. https://doi.org/10.1016/j.tplants.2016.01.013

Wright, S. (1921). Correlation and causation. Journal of Agricultural Research, 20(7), 557-585.

Wu, Q., Pagès, L., \& Wu, J. (2016). Relationships between root diameter, root length and root branching along lateral roots in adult, field-grown maize. Annals of Botany, 117(3), 379-390. https://doi.org/10.1093/aob/ mev185

Zahedi H., \& Abbasi S. (2015). Effect of plant growth promoting rhizobacteria (PGPR) and water stress on phytohormones and polyamines of soybean. Indian Journal of Agriculture Research, 49, 427-431. https://doi.org/10.18805/ijare.v49i5.5805

Zeist, A. R., Oliveira, J. R. F. de, Lima Filho, R. B. de., Silva, M. L. de. S., \& Resende, J. T. V. de. (2014). Comparação de métodos de estimativa de área foliar em morangueiro. Pesquisa Agropecuária Gaúcha, 20(1/2), 33-41.

Zuffo, A. M., Júnior, J. M. Z., Fonseca, W. L., Zambiazzi, E. V., Oliveira, A. M. de., Guilherme, S. R., ... Pinto, A. R. S. (2017). Path Analysis in Soybean Cultivars Grown under Foliar Spraying and Furrow Inoculation with Azospirillum brasilense. Journal of Agricultural Science, 9(10), 137-144. https://doi.org/10.5539/ jas.v9n10p137

\section{Copyrights}

Copyright for this article is retained by the author(s), with first publication rights granted to the journal.

This is an open-access article distributed under the terms and conditions of the Creative Commons Attribution license (http://creativecommons.org/licenses/by/4.0/). 